\title{
PREPARATION, SPECTROSCOPIC CHARACTERIZATION OF A NEW Cd(II) COMPLEX CONTAINING TRIDENTATE NNO SCHIFF BASE DERIVED AND X-RAY CRYSTALLOGRAPHIC STRUCTURAL STUDY OF 3,4,5-TRIHYDROXYBENZOIC ACID[1-(PYRIDYL)-ETHYLIDENE]HYDRAZONE
}

\author{
ABEER A. ALHADI ${ }^{1}$, SHAYMA A. SHAKER ${ }^{2,}{ }^{*}, N U R A$ SULEIMAN $G^{1}$, WAGEE A. \\ YEHYE ${ }^{I}$, HAPIPAH MOHD ALI ${ }^{1}$

\begin{abstract}
${ }^{1}$ Department of Chemistry, College of Sciences, University of Malaya, 50603 Kuala Lumpur, Malaysia, ${ }^{2}$ Department of Sciences and Mathematics, Universiti
\end{abstract} \\ Tenaga Nasional, KM 7 Jalan Kajang-Puchong, 43009 Kajang, Selangor, Malaysia.
}

(Received: February 9, 2012 - Accepted: May 2, 2012)

\begin{abstract}
A new Cd(II) complex with a tridentate Schiff base derivative which was obtained from condensation of gallic hydrazid with 2-acetylpyridine has been prepared. The structure of the ligand 3,4,5-Trihydroxybenzoic acid[1-(pyridyl)-ethylidene]hydrazone (GAPy) was confirmed using the X-ray structure analysis. The elemental analysis, FTIR, UV-Vis, ${ }^{1} \mathrm{H}$ NMR spectral and Thermal analysis indicates that the Schiff base ligand GAPy is a tridentate ligand which is coordinated with the $\mathrm{Cd}$ (II) complex through $\mathrm{N}, \mathrm{N}$ and $\mathrm{O}$ atoms. Thus, the acetate ion is a bidentate ligand that is coordinated with the metal ion through two $\mathrm{O}$ atoms.
\end{abstract}

Keywords: Schiff base derivatives, Cd(II) complexes, hydrazone derivatives complexes, spectroscopic characterization.

\section{INTRODUCTION}

Schiff bases from gallic hydrazides are well known as polydentate ligands which are considered as an important class of ligands in coordination chemistry. ${ }^{1}$ Thus, gallic hydrazide and its substituted derivative have been prepared and characterized during the past few years. ${ }^{2-9}$ Metal complexes of tridentate Schiff base ligands with donor atoms such as (NNO) have attracted considerable attention because they display anti-fungal activity against various fungal such as Aspergillus Flavus, Trichophyton longifusus, Candida albicans and Microsporum canis. ${ }^{4} 10$ Moreover, these complexes display remarkable antitumor activity against HL60 and A-549 cancer cell lines, and also display antioxidative, anti-inflammatory, antimutagenic, anticarcinogenic and antiallergic activities. ${ }^{11}$ The hydrazone group has two imino and amino nitrogen atoms whose valance electrons differ in their degree of hybridization. The possibility of chelate formation via a hydrogen bond between the nitrogen atom of a gallic hydrazones and the hydrogen atom of the $\mathrm{OH}$ group of salicyldehyde has been reported. ${ }^{12-15}$ Since little work has been reported on Cd(II) complex containing 3,4,5-Trihydroxybenzoic acid[1-(pyridyl)-ethylidene]hydrazide. We prepared the schiff base from gallic hydrazide and synthesized the complex with Cd(II) ion. Uv-Vis, IR, and TGA spectroscopy as well as X-ray diffraction were used to examine the coordination site of the ligand and the geometry of the complex.

\section{EXPERIMENTAL}

\subsection{Techniques and Materials}

All chemicals were obtained from commercial sources and were used without further purifications (Cd(II)acetate, gallic hydrazide, 2-acetylpyridine, ethanol, DMSO, DMF, Triethylamine, KBr) from Merck (Darmstadt, Germany).

Infrared spectra were obtained using $\mathrm{KBr}$ discs $\left(4000-400 \mathrm{~cm}^{-1}\right)$ on a Perkin-Elmer FT-IR spectrometer (Kyoto, Japan). Measurement of UV-Vis spectra were carried out using a Shimadzu UV-VIS spectrophotometer UV160 (Hitachi, Tokyo, Japan) in $10^{-3} \mathrm{M}$ DMSO solution. Thermal analysis of the complex was performed on a Perkin-Elmer Pyris Diamond DTA/TG Thermal System under a nitrogen atmosphere at a heating rate of $10^{\circ} \mathrm{C} / \mathrm{min}$ and within a heating range of $30-900^{\circ} \mathrm{C}$. Elemental analysis $(\mathrm{C}, \mathrm{H}, \mathrm{N})$ was performed by using a Flash EA 1112 Series elemental analyzer (St. Joseph, MI, USA). Crystal data were obtained from APEX2 ${ }^{16}$; cell refinement: SAINT ${ }^{16}$; data reduction: SAINT. The program (s) used to solve the structure was SHELXS97 ${ }^{17}$; the program used to refine the structure was SHELXL97 ${ }^{17}$; molecular graphics were analyzed using $X S E E D^{18}$; and the software used to prepare the data for publication was publCIF.

2. 2 Synthesis of the ligand 3,4,5-trihydroxybenzoic acid[1-(pyridyl)ethylidene]hydrazone

The Schiff base was prepared by adding $25 \mathrm{~mL}$ of an ethanolic solution of gallic hydrazide $(1.84 \mathrm{~g}, 0.01 \mathrm{mmol})$ to $25 \mathrm{~mL}$ of an ethanol solution of 2-acetylpyridine $(1.21 \mathrm{~mL}, 0.01 \mathrm{mmol})$. The mixture was refluxed in a water bath for 6-8 h. The white precipitate formed was filtered, washed 3 times with ethanol and crystallized with DMF. Elemental analysis found (calc.) \%: C, 57.99 (58.53); H, 4.56 (4.56); N, 14.06 (14.63). The m.p was $155^{\circ} \mathrm{C}$ and the yield was $65 \%$.

\subsection{Synthesis of the Cd(II) complex}

An ethanol solution $(35 \mathrm{~mL})$ of $\mathrm{Cd}(\mathrm{II})$ acetate $(0.088 \mathrm{~g}, 0.33 \mathrm{mmol})$ was added to an ethanol solution of 3, 4, 5-trihydroxybenzoic acid [1(pyridyl)- ethylidene]hydrazone $(0.20 \mathrm{~g}, 0.66 \mathrm{mmol})$ together with 4 drops of triethylamine. The mixture was refluxed at room temperature for $10 \mathrm{~h}$. The product precipitated as a brown solid and was recrystallized from DMSO. Elemental analysis found (calc.) \%: C, 38.99(39.53); H, 2.75(2.95); N, 7.59 (7.68). The m.p was $255^{\circ} \mathrm{C}$ and the yield was $60 \%$.

\section{RESULTS AND DISCUSSION}

The Schiff base (GAPy) was obtained with a good yield by condensing gallic hydrazide with 2-acetylpyridine. Thus, the reaction of the Schiff base with the metal salt gave a complex with the general formula $\left[\mathrm{Cd}(\mathrm{GAPy})(\mathrm{AcO})_{2}\right] \cdot 2 \mathrm{H}_{2} \mathrm{O}$ where GAPy=3,4,5-trihydroxybenzoic acid[1-(pyridyl)-ethylidene]hydrazide and $\mathrm{AcO}=$ acetate ion. The prepared complex was solid, and was insoluble in most organic solvents such as acetone, benzene, and dichloromethane except for DMSO. The results of elemental analysis were in good agreement with the calculated values from the proposed empirical formula.

3.1 Uv-Vis spectral studies

The Uv-Vis spectrum of the ligand GAPy in DMSO showed absorption bands at 270, 276 and 280,289, $329 \mathrm{~nm}$ which were attributed to $\pi \rightarrow \pi^{*}$ and $\mathrm{n} \rightarrow \pi^{*}$ transitions respectively. The diamagnetic $\mathrm{Cd}(\mathrm{II})$ complex exhibited absorption bands at 285 and $293 \mathrm{~nm}$ which were due to $\pi \rightarrow \pi^{*}$ transitions. Thus, the spectrum showed charge transfer LMCT at $302 \mathrm{~nm}$. This is because the electronic configuration of the $\mathrm{Cd}(\mathrm{II})$ complex is $d^{10}$ which indicates the absence of d-d electronic transition. Moreover, the absorption bands showed a red shift with a hyper chromic effect which supported the coordination of the ligand with the metal atom..$^{19,20}$

3.2 IR spectral studies

The infrared spectra of the free ligand GAPy showed strong bands at 3399 and $3351 \mathrm{~cm}^{-1}$, corresponding to $v(\mathrm{ph}-\mathrm{OH})$ and $v(\mathrm{NH})$ respectively. These bands appeared in the spectra of the complex at 3439 and $3393 \mathrm{~cm}^{-1}$ which indicated that the $\mathrm{OH}$ and $\mathrm{NH}$ groups were not coordinated with the $\mathrm{Cd}(\mathrm{II})$ ion. However, the spectrum of the ligand showed strong bands at 1618 and $1650 \mathrm{~cm}^{-1}$, corresponding to the $v(\mathrm{C}=\mathrm{N})$ of azomethine and pyridine respectively. These bands were shifted to lower frequencies by 16 and $18 \mathrm{~cm}^{-1}$ in the spectrum of the complex. Furthermore, the $v(\mathrm{~N}-\mathrm{N})$ band was observed at $1032 \mathrm{~cm}^{-1}$, but was shifted to higher frequency at $1042 \mathrm{~cm}^{-1}$ after complex formation. The coordination through the $\mathrm{N}$ atom was further supported by the occurrences of new bands at $400-450 \mathrm{~cm}^{-1}$ in the spectra of the complex, which 
were tentatively assigned to $v(\mathrm{M}-\mathrm{N})$. Moreover, the $v(\mathrm{C}=\mathrm{O})$ that appeared at $1630 \mathrm{~cm}^{-1}$ in the spectra of the free ligand was shifted to a lower frequency by $10 \mathrm{~cm}^{-1}$. This indicates that the ligand GAPy is also coordinated with Cd(II) through the $\mathrm{O}$ atom. ${ }^{11,21,22}$

Asymmetrical and symmetrical vibrations of $v\left(\mathrm{COO}^{-}\right)$were noticed at 1420 and $1328 \mathrm{~cm}^{-1}$, respectively in the spectra of the Cd(II) complex. Thus, the complex also exhibited weak bands between 519-564 $\mathrm{cm}^{-1}$ which were attributed to $v(\mathrm{M}-\mathrm{O})$. This indicates that the acetate group is coordinated with the metal ion through the two $\mathrm{O}$ atoms. ${ }^{11,23-25}$ Finally, the spectrum of the $\mathrm{Cd}(\mathrm{II})$ complex showed a band at $3439 \mathrm{~cm}^{-1}$ which was attributed to the $v\left(\mathrm{H}_{2} \mathrm{O}\right)$ crystal water molecule.

$3.3{ }^{1} H$ NMR spectral studies

${ }^{1} \mathrm{H}$ NMR spectrum of the free ligand GAPy shows singlet signal at $\delta$ 7.62 which attributed to the $\mathrm{NH}$ group. This signal was noticed in the $\mathrm{Cd}(\mathrm{II})$ complex, this appearance of $\mathrm{NH}$ group in the complex which suggested that the coordination is impossible through the NH [26]. Thus, the methyl group was observed as a sharp singlet at 2.39. ${ }^{27,28}$ The signals due to the benzene and pyridine ring were appeared in the range 6.90-9.40.

3.4 Thermal gravimetric Analysis of Cd(II) complex

The Cd(II) complex is stable up to $35^{\circ} \mathrm{C}$. Decomposition started at 35.26 ${ }^{\circ} \mathrm{C}$ and was completed at $658.73{ }^{\circ} \mathrm{C}$. Furthermore, the percentage weight losses corresponding to various steps in the TGA curve. ${ }^{29-33}$ Moreover, the Cd(II) complex decomposed and produced $\mathrm{CdO}$ as a residue [found (calculated)\%: 18.11(20.20)] in seventh steps in the temperature range 35.26-158.41, 163.97$206.22,210.67-285.16,291.83-342.98,350.76-469.72,477.51-695.36$ and $607.59-658.73^{\circ} \mathrm{C}$. In the decomposition process of the $\mathrm{Cd}(\mathrm{II})$ complex, the mass losses corresponded to those of $2\left(\mathrm{H}_{2} \mathrm{O}\right), \mathrm{C}_{7} \mathrm{H}_{6} \mathrm{O}_{4} \mathrm{~N}, 2\left(\mathrm{CH}_{3} \mathrm{CO}_{2}\right), \mathrm{C}_{7} \mathrm{H}_{7} \mathrm{~N}$ and $\mathrm{NO}$ molecules respectively. The important thermal decomposition data of the Cd(II) complex are listed in Table 1 .

Table 1. TGA data of the $\left[\mathrm{Cd}(\mathrm{GAPy})\left(\mathrm{CH}_{3} \mathrm{COO}\right)_{2}\right] \cdot 2 \mathrm{H}_{2} \mathrm{O}$.

\begin{tabular}{|c|c|c|c|c|c|}
\hline Complex & Step & $\begin{array}{c}\text { Temperature } \\
{ }^{\circ} \mathrm{C}\end{array}$ & $\begin{array}{c}\text { Weight loss (\%) } \\
\text { Found(Calculated) }\end{array}$ & Assignment & $\begin{array}{c}\text { Residue \% } \\
\text { Found(Calculated) }\end{array}$ \\
\hline \multirow{7}{*}{$\mathrm{Cd}(\mathrm{II})$} & 1 & $35.26-158.41$ & $6.0(6.4)$ & $2 \mathrm{H}_{2} \mathrm{O}$ & \multirow{7}{*}{$\begin{array}{c}\mathrm{CdO} \\
18.1(20.2)\end{array}$} \\
\hline & 2 & $163.97-206.22$ & $2.6(2.7)$ & $\mathrm{N}-\mathrm{H}$ & \\
\hline & 3 & $210.67-285.16$ & $16.0(15.6)$ & $\mathrm{C}_{6} \mathrm{H}_{5} \mathrm{O}_{3}$ & \\
\hline & 4 & 291.83-342.98 & $12.5(13.0)$ & $\mathrm{CO}$ & \\
\hline & 5 & $350.76-469.72$ & $21.1(21.3)$ & $2\left(\mathrm{CH}_{3} \mathrm{CO}_{2}\right)$ & \\
\hline & 6 & $477.51-599.36$ & 18.3(18.9) & $\mathrm{C}_{7} \mathrm{H}_{7} \mathrm{~N}$ & \\
\hline & 7 & $607.59-658.73$ & $5.2(5.4)$ & $\mathrm{NO}$ & \\
\hline
\end{tabular}

3.5 X-ray data of the ligand GAPY

The compound of GAPy as shown in Fig. 1, crystallizes as triclinic and also as a series of hydrogen-bonded clusters with water molecules. The nitrogen group on the pyridine group forms an intramolecular hydrogen bond with the $\mathrm{N}$ atom of the $\mathrm{C}=\mathrm{N}$ double bond. The two hydroxyl group atoms of the benzylidine group as hydrogen-bond donors to the oxygen atoms of the two water molecules. The hydroxyl group on the benzohydrazone group is a hydrogen-bond donor to one acceptor site, whereas each water molecule is a hydrogen bond donor to two acceptor sites. All the crystal data, bond lengths, bond angles and hydrogen bond length are listed in Tables 2, 3 and 4.

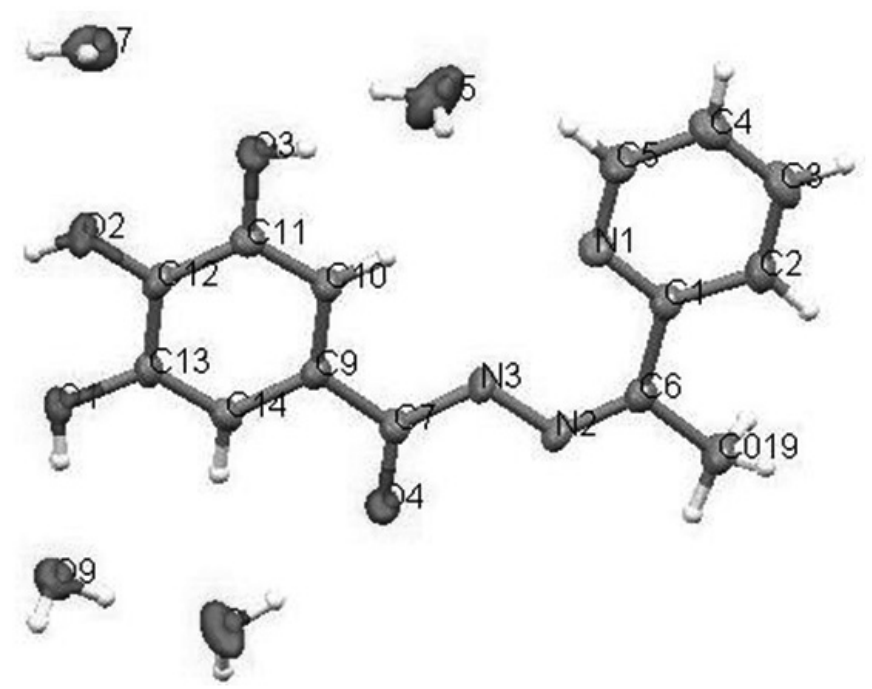

Fig. 1. Molecular structure of GAPy with thermal ellipsoid plot of $\mathrm{C}_{14} \mathrm{H}_{18} \mathrm{~N}_{3} \mathrm{O}_{8}$ at $70 \%$ probability level.

\begin{tabular}{|c|c|}
\hline Identification code & GAPy \\
\hline Empirical formula & $\mathrm{C}_{14} \mathrm{H}_{18} \mathrm{~N}_{3} \mathrm{O}_{8}$ \\
\hline Formula weight & 302.27 \\
\hline Temperature / K & 296.0 \\
\hline Crystal system & triclinic \\
\hline Space group & P-1 \\
\hline $\mathrm{a} / \AA, \mathrm{b} / \AA ⿻ \mathrm{c} / \AA$ & $6.6282(7), 9.9326(7), 12.8906(11)$ \\
\hline$\alpha /^{\circ}, \beta /{ }^{\circ}, \gamma /{ }^{\circ}$ & $79.982(2), 80.995(2), 76.5060(10)$ \\
\hline Volume / $\AA^{3}$ & $806.67(12)$ \\
\hline Z & 2 \\
\hline$\rho_{\text {calc }} / \mathrm{mg} \mathrm{mm}^{-3}$ & 1.244 \\
\hline$\mu / \mathrm{mm}^{-1}$ & 0.097 \\
\hline $\mathrm{F}(000)$ & 314 \\
\hline Crystal size $/ \mathrm{mm}^{3}$ & $0.33 \times 0.14 \times 0.11$ \\
\hline $2 \Theta$ range for data collection & 3.24 to $61.08^{\circ}$ \\
\hline Index ranges & $-8 \leq \mathrm{h} \leq 6,-14 \leq \mathrm{k} \leq 10,-17 \leq 1 \leq 17$ \\
\hline Reflections collected & 2552 \\
\hline Independent reflections & $2237[\mathrm{R}($ int $)=0.0358]$ \\
\hline Data/restraints/parameters & $2237 / 12 / 254$ \\
\hline Goodness-of-fit on $\mathrm{F}^{2}$ & 0.804 \\
\hline Final $R$ indexes $[\mathrm{I}>2 \sigma(\mathrm{I})]$ & $\mathrm{R}_{1}=0.0462, \mathrm{wR}_{2}=0.1239$ \\
\hline Final $\mathrm{R}$ indexes [all data] & $\mathrm{R}_{1}=0.0555, \mathrm{wR}_{2}=0.1354$ \\
\hline Largest diff. peak/hole / e $\AA^{-3}$ & $0.433 /-0.339$ \\
\hline
\end{tabular}




\begin{tabular}{|c|c|c|c|}
\hline \multicolumn{5}{|c|}{ Table 3 Bond Angles for GAPy. } \\
\hline Atom & Atom & Atom & Angle $^{\circ}$ \\
\hline C7 & $\mathrm{N} 3$ & $\mathrm{~N} 2$ & $118.18(18)$ \\
\hline $\mathrm{C} 6$ & $\mathrm{~N} 2$ & $\mathrm{~N} 3$ & $118.18(19)$ \\
\hline O2 & $\mathrm{C} 12$ & $\mathrm{C} 11$ & $118.22(19)$ \\
\hline O2 & $\mathrm{C} 12$ & $\mathrm{C} 13$ & $122.50(15)$ \\
\hline $\mathrm{C} 13$ & $\mathrm{C} 12$ & $\mathrm{C} 11$ & $119.2(2)$ \\
\hline O3 & $\mathrm{C} 11$ & $\mathrm{C} 12$ & $117.02(19)$ \\
\hline $\mathrm{O} 3$ & $\mathrm{C} 11$ & $\mathrm{C} 10$ & $122.48(15)$ \\
\hline $\mathrm{C} 10$ & $\mathrm{C} 11$ & $\mathrm{C} 12$ & $120.5(2)$ \\
\hline $\mathrm{C} 5$ & $\mathrm{~N} 1$ & $\mathrm{C} 1$ & $118.95(16)$ \\
\hline $\mathrm{N} 1$ & $\mathrm{C} 5$ & $\mathrm{C} 4$ & $122.9(2)$ \\
\hline $\mathrm{N} 1$ & $\mathrm{C} 1$ & $\mathrm{C} 2$ & $121.60(19)$ \\
\hline $\mathrm{N} 1$ & $\mathrm{C} 1$ & $\mathrm{C} 6$ & $118.65(15)$ \\
\hline $\mathrm{C} 2$ & $\mathrm{C} 1$ & $\mathrm{C} 6$ & $119.7(2)$ \\
\hline $\mathrm{C} 13$ & $\mathrm{C} 14$ & $\mathrm{C} 9$ & $119.96(19)$ \\
\hline
\end{tabular}

\begin{tabular}{|c|c|c|}
\hline \multicolumn{3}{|c|}{ Table 4 Bond Lengths for GAPy. } \\
\hline Atom & Atom & Length/ $\mathbf{A}$ \\
\hline O2 & C12 & $1.362(3)$ \\
N3 & N2 & $1.373(3)$ \\
N3 & C7 & $1.364(2)$ \\
N2 & C6 & $1.299(2)$ \\
O4 & C7 & $1.244(2)$ \\
O1 & C13 & $1.3764(19)$ \\
C12 & C11 & $1.403(2)$ \\
C12 & C13 & $1.394(3)$ \\
C11 & O3 & $1.369(3)$ \\
C11 & C10 & $1.381(3)$ \\
N1 & C5 & $1.338(3)$ \\
\hline
\end{tabular}

\section{CONCLUSION}

The interaction of the schiff base derived from gallic hydrazide and an acetate ion with the $\mathrm{Cd}(\mathrm{II})$ ion yielded a mixed ligand complex with the general formula $\left[\mathrm{Cd}(\mathrm{GAPy})(\mathrm{AcO})_{2}\right] \cdot 2 \mathrm{H}_{2} \mathrm{O}$ where $\mathrm{GAPy}=3,4,5$-trihydroxybenzoic acid[1-(pyridyl)-ethylidene]hydrazone and $\mathrm{AcO}=\mathrm{CH} 3 \mathrm{COO}^{-}$. The complex is insoluble in most organic solvents with the exception of DMSO. The structure of the complex based on Uv-Vis, IR, ${ }^{1} \mathrm{H}$ NMR, and TGA spectroscopy and $\mathrm{X}$-ray structure analysis indicates that the Schiff base GAPy exists as a tridentate coordinated with the metal ion through the $\mathrm{O}$ atom of $(\mathrm{C}=\mathrm{O})$ and two of the $\mathrm{N}$ atoms of azomethine and pyridine. Thus, the acetate ion is coordinated with the metal ion via two oxygen atoms. Therefore, from the results presented the $\mathrm{Cd}(\mathrm{II})$ complex has the distorted octahedral geometry as shown in Fig. 2.

\section{SUPPLEMENTARY DATA}

Crystallography data of the ligand 3,4,5-trihydroxybenzoic acid[1(pyridyl)-ethylidene]hydrazone has been deposited with the Cambridge Crystallographic Data Center as supplementary publication No. CCDC. 793961.Copies of the data can be obtained, free of charge, by applying to CCDC, 12 Union Road, Cambridge CB2 1EZ, UK, (Fax: +44-(0)1223-336033 or e-mail: deposit@ccdc.cam.ac.UK.

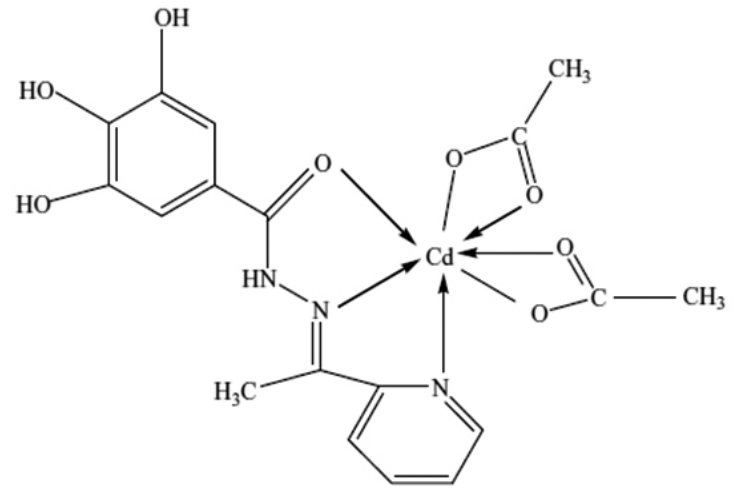

Fig. 2 Structure of the $\left[\mathrm{Cd}(\mathrm{GAPy})(\mathrm{AcO})_{2}\right]$ complex.

\section{ACKNOWLEDGEMENT}

We wish to thank the University of Malaya for grants (PPP PS 252/ 2009 A) and staff members at the Faculty of Science for their academic and technical assistance.

\section{REFERENCES}

1. A. S. Shayma, F. Yang, A. S. Abbas, European Journal of Scientific Research, 33, 4, 702 (2009).

2. K. Feist, F. Klatt, W. Awe, Archiv der pharmazie and Berichte der Deutschen pharmazeutischen Gesellschaft 272, 221-35, Coden: APBDAJ ISSN: 0376-0367 (1934).

3. Z. T. Maqsood, K. M. Khan, V. J. R. A. Ashio, Z. H. Chohan, T. M. Mahroof, Journal of Enzyme Inhibition and Medical Chemistry, 21, 1, 37 (2006).

4. D. Zhu, L. Zhang, Faming Zhuanli Shenqing, (2007).

5. A. A. Abeer, M. S. Siti, M. A. Hapipah, T. R. Ward, A. A. Mahmood, Acta Cryst E, 65, o1373 (2009).

6. A. A. Abeer, M. A. Hapipah, P. Subramaniam, T. R. Ward, W. N. Seik, Acta Cryst E, 64, o1584 (2008).

7. A. A. Abeer, M. A. Hapipah, W. N. Seik, Acta Cryst E, 65, o910 (2009).

8. A. A. Abeer, M. A. Hapipah, W. N. Seik, Acta Cryst E, 65, o908 (2009).

9. A. A. Abeer, M. A. Hapipah, W. N. Seik, Acta Cryst E, 65, 0909 (2009).

10. M. A. Akbar, R. Bose, J Inorg Nucl Chem., 39, 265 (1977).

11. Z. Ling, H. Z. Jian, Z. Yuan, Journal of Chemical Research, 630 (2008),

12. S. Arunkumar, N. Ramalakshim, T. Saraswathy, L. Aruloly, Indian Journal of Hetrocyclic Chemistry, 16, 1, 29 (2006).

13. X. J. Hong, G. Z. Wei, Z. Yun, L. W. Sue, Molecules, 7, 549 (2002).

14. M. Morteza, J. Shiva, A. M. Sayed, Spectrochimica Acta Part A, 73, 231 (2009).

15. Z. S. Xian, L. H. Zhen, W. Zhou, H. Y. Bao, M. C. Xiao, Anorg. Allg. Chem, 631, 919 (2004) .

16. Bruker, APEX2 and SAINT, Bruker AXS Inc, Madison, Wisconsin: USA, 2007.

17. G. M. Sheldrick, Acta Crystallogr A, 64, 112 (2008). Doi: 10.1107/ S0108767307043930.

18. L. J. Barbour, J Supramol Chem, 1, 189 (2001). Doi: 10.1016/S14727862(02)00030-8.

19. A. B. P. Lever, Inorganic Electronic Spectroscopy, Elsevier publishing Co. Ltd: New York, 1968.

20. S. D. Russell, Physical Methods In Inorganic Chemistry, Van Nostrand Reinhold Inc: US, 1965.

21. G. F. Desousa, R. H. Franciscob, M. T. Gambardella, R. H. Santosb, A. Abrasc, J Braz Chem Soc., 12 6, 722 (2001)

22. H. Keypour, S. Salehzadeh, R. G. Pritchard, R. V. Parish, Molecules, ISSN. 1420-3049 (2001). See http//www.m.dpi.org.

23. A. D. Cross, J. Alan, An Introduction to Practical Infrared Spectroscopy, Butterworths: London, 1969.

24. R. J. Dyer, Application of Absorption Spectroscopy of Organic Compounds, Prentice-Hall: New Jersey, 1965.

25. G. Socrates, Infrared Characteristic Group Frequencies, WielyInterscience publication: New York, 1980.

26. A. S. Shayma, E-Journal of Chemistry, 7, 4, 1598 (2010). 
27. S. Banerjee, A. Ghosh, P. G. Lassahn, C. Janiak, Polyhedron, 24, 593 (2005).

28. L. Pavia, Kriz, Introduction to Spectroscopy, 3 ed., Thomson Learning: USA, 2001.

29. Sonmez, M. Levant, A. Sekerci, Russian Journal of Coordination Chemistry, 30, 655 (2004).
30. L. S. Prabhumirashi, J. K. Khoje, Thermochimica Acta, 383, 109 (2002).

31. A. A. Saleh, S. M. Khalil, M. F. Eid, M. A. Elghamry, J Coord Chem, 56, 467(2003).

32. S. H. Sawsan, Indian Journal of Chemistry, 46 A, 582 (2007).

33. E. Canfolat, M. Kaya, Turk Journal of Chemistry, 29, 409 (2005). 